\title{
Pengaruh Current Ratio, Return on Equity, Debt to Equity Ratio dan Ukuran Perusahaan terhadap Price Book Value (The Effect of Current Ratio, Return on Equity, Debt to Equity Ratio and Company Size on Price Book Value)
}

\section{Witri Aryani $^{1^{*},}$ Mia Laksmiwati ${ }^{2}$}

Fakultas Ekonomi dan Bisnis, Universitas Budi Luhur, Jakarta Selatan ${ }^{1,2}$ aryaniwitri@gmail.com $^{1^{*}}$, mialaksmiwati@budiluhur.ac.id $^{2}$

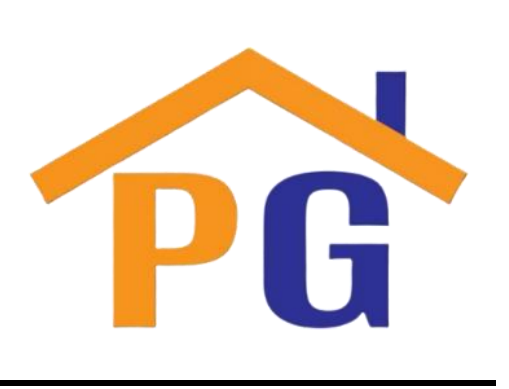

Riwayat Artikel

Diterima pada 20 Oktober 2020

Direvisi pada 1 April 2021

Disetujui pada 21 Juni 2021

\begin{abstract}
Purpose: This study aimed to determine the effect of CR, ROE, DER and Company Size on PBV of Public Companies in Chemical Sub Sector Listed on the Indonesia Stock Exchange Period 20132017.
\end{abstract}

Research Methodology: The sampling technique used was a purposive sampling method. The researched population was 11 companies and the samples used were 8 Public Chemical Sub Sector Companies Listed on the Indonesia Stock Exchange. The data used was multiple linear regression analysis, tested using the Statistical Package for the Social Science (SPSS) and Microsoft Excel 2016. In addition, the data used were secondary data in the form of complete financial statements during the 2013-2017 period.

Results: The study results indicate that the DER variable has a positive and significant effect on PBV. Company Size has a positive and significant effect on PBV. In contrast, the $\mathrm{CR}$ and $\mathrm{ROE}$ variable do not affect the PBV.

Keywords: Current Ratio, Return on Equity, Debt to Equity Ratio, Company Size, Price Book Value

How to cite: Aryani, W., \& Laksmiwati, M. (2021). Pengaruh Current Ratio, Return on Equity, Debt to Equity Ratio dan Ukuran Perusahaan terhadap Price Book Value. Studi Akuntansi, Keuangan, dan Manajemen, 1(1), 17-24.

\section{Pendahuluan}

Perkembangan dunia industri di Indonesia saat ini sedang mengalami peningkatan dan perkembangan yang tinggi, hal tersebut dapat dilihat semakin maraknya perusahaan indutri yang tumbuh dan berkembang pesat di segala macam bidang usahanya. Tujuan utama perusahaan tentunya untuk memperoleh keuntungan laba yang sebesar-besarnya atau mencapai laba yang maksimal dan dapat memakmurkan atau mensejahterakan pemilik perusahaan dan juga para investor yang telah berinvestasi.

Menurut penelitian I Gusti Ngurah Gede Ruganda dan Gede Merta Sudiarta (2016) Nilai perusahaan dapat diukur aspek, salah satunya dengan menggunakan harga pasar saham perusahan karena harga saham saham perusahaan merupakan mencerminakan penilaian para investor sacara keseluruhan atas setiap ekuitas yang dimiliki. Manurut Fitri Dwi Jayanti (2018) Nilai perusahaan tinggi tercermin dari harga saham yang tinggi.

Calon investor mendapatkan gambaran atas nilai aset yang dimiliki oleh suatu perusahaan melalui harga saham apabila harga saham meningkat maka nilai perusahaan akan meningkat begitu pula sebaliknya. Hal tersebut membuat para investor dapat memperkirakan return yang akan didapat dan sekaligus membuat keputusan untuk melakukan investasi di perusahaan tersebut. Penelitian ini menggunakan 5 variebel yaitu CR, ROE, DER dan Ukuran Perusahaan terhadap PBV. Populasi yang digunakan dalam penelitian ini yaitu perusahaan Sub Sektor Kimia yang terdaftar di Bursa Efek Indonesia. 


\section{Kajian Teori}

\subsection{Variabel Penelitian}

\subsubsection{Nilai Perusahaan}

Menurut Harmono (2017) Nilai Perusahaan dapat diukur melalui harga saham di pasar, harga saham perusahaan merupakan refleksi penilaian oleh publik terhadap kinerja yang rill. Menurut Hardjadi (2015) PBV menggambarkan seberapa besar pasar menghagai nilai buku saham suatu perusahaan. PBV dipergunakan untuk mengetahui nilai suatu perusahaan dengan rumus:

$$
\text { Price Book Value }=\frac{\text { Harga Saham }}{\text { Nilai Buku }}
$$

\subsubsection{Current Ratio}

Menurut Harahap (2015) Rasio Likuiditas menggambarkan kemampuan perusahaan untuk menyelesaikan kewajiban jangka pendeknya. Semakin besar perbandingan aset lancar dengan utang lancar makin tinggi kemampuan dalam melunasi kewajiban jangka pendeknya. Adapun rumusnya sebagai berikut:

$$
\text { Current Ratio }=\frac{\text { Aset Lancar }}{\text { Utang Jangka Pendek }}
$$

\subsubsection{Return On Equity}

Menurut Hery (2018) ROE menunjukkan berapa besar kontribusi ekuitas dalam menciptakan laba bersih. Makin tinggi hasil pengembalian ekuitas makin tinggi laba bersih yang dihasilkan dari ekuitas. ROE rumusnya:

$$
\text { Return On Equity }=\frac{\text { Laba Bersih }}{\text { Total Ekuitas }}
$$

\subsubsection{Debt To Equity Ratio}

Menurut Hermanto dan Agung (2015) menyatakan DER mengukur presentase dana yang disediakan oleh para kreditur dengan modal perusahaan untuk membayar utang. Utang yang dimaksudkan di sini adalah utang lancar dan utang jangka panjang.

$$
\text { Debt To Equity Ratio }=\frac{\text { Total Liabilities }}{\text { Total Shareholders' Equity }}
$$

\subsubsection{Ukuran Perusahaan}

Menurut Hery (2017) Ukuran perusahan merupakan skala yang menunjukkan besar atau kecilnya suatu perusahaan. Ukuran perusahaan melalui total aset cenderung lebih stabil daripada melalui penjualan. Hal ini disebabkan karena penjualan cenderung lebih fluktuasi setaip tahun daripada total aset. Adapun Rumusnya adalah:

$$
\text { Ukuran Perusahaan }=\text { Ln }(\text { Total Aset })
$$




\subsection{Kerangka Pemikiran}

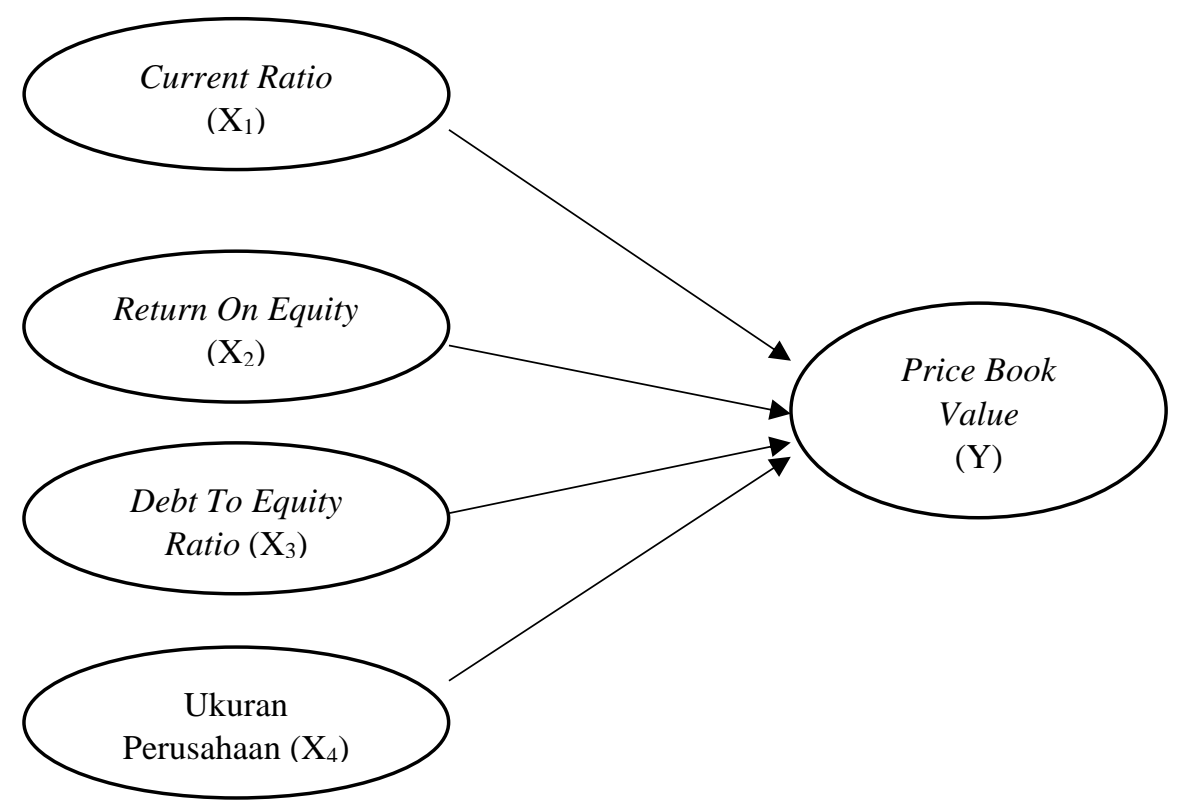

Gambar 1. Kerangka Pemikiran

\subsection{Hipotesis Penelitian}

\subsubsection{Pengaruh Current Ratio terhadap Price Book Value}

Tinggi rendahnya rasio ini akan memperngaruh minat para investor untuk berinvestasi. Tingginya CR dapat menunjukkan bahwa perusahaan tersebut memiliki dana untuk membayar dividen dan sekaligus mempunya dana internal yang besar, sehingga perusahaan tersebut menggunakan dana internalnya terlebih dahulu untuk membiayai investasinya sebelum menggunakannya untuk biaya eksternal melalui hutang. Adapun hipotesisnya sebagai berikut:

\section{$\mathrm{H}_{1} \quad$ : CR berpengaruh signifikan terhadap PBV}

\subsubsection{Pengaruh Return On Equity terhadap Price Book Value}

Para Investor tentunya akan tertarik pada perusahaan yang mengahasilkan laba atau tingkat ROE tinggi hal ini tentunya akan mengakibatkan harga saham pada perusahaan tersebut akan meningkat. Adapun hipotesisnya sebagai berikut :

$\mathrm{H}_{2} \quad$ : ROE berpengaruh signifikan terhadap PBV

\subsubsection{Pengaruh Debt To Equity Ratio terhadap Price Book Value}

Tingginya utang yang dimiliki perusahaan akan membuat perusahaan terbebani dalam menggunakan modal internal untuk membayar utang. Begitu pula sebaliknya apabila utang pada perusahaan rendah, maka modal (Dana Internal) yang dimiliki perusahaan mampu menutupi utang-utangnya. Hal ini dapat membuat para investor tertarik untuk menginvestasikan dananya di perusahaan tersebut. Hipotesisnya sebagai berikut:

\section{$\mathrm{H}_{3} \quad$ : DER berpengaruh signifikan terhadap PBV}

\subsubsection{Pengaruh Ukuran Perusahaan terhadap Price Book Value}

Perusahaan yang memiliki ukuran perusahaan yang tinggi atau perusahaan yang berskala tinggi tentunya perusahaan tersebut dapat dengan mudah memperoleh dana internal maupun eksternal. Hal ini dapat membuat para investor menilai bahwa kinerja pada perusahan tersebut baik dalam waktu jangka panjang nya. Adapun Hipotesisnya sebagai berikut:

$\mathrm{H}_{4} \quad$ : Ukuran Perusahaan berpengaruh signifikan terhadap PBV 


\section{Metode Penelitian}

\subsection{Populasi Penelitian}

Populasi dalam penelitian ini adalah 11 emiten yang tergabung dalan sub sektor kimia yang terdaftar di Bursa Efek Indonesia periode 2013-2017.

\subsection{Sampel Penelitian}

Teknik pengambilan sampel dalam penelitian ini adalah purpose sampling, jumlah yang memenuhi kriteria tersebut sebanyak 8 emiten.

\subsection{Model dan Alat Penelitian}

Model yang digunakan untuk menguji hipotesa terkait pengaruh CR, ROE, DER dan Ukuran Perusahaan terhadap PBV adalah menggunakan regresi linier berganda. Adapun persamaan yang digunakan yaitu:

$$
\mathbf{Y}=\mathbf{a}+\mathbf{B}_{1} \mathbf{X}_{1}+\mathbf{b}_{2} \mathbf{X}_{2}+\mathbf{b}_{3} \mathbf{X}_{3}+\mathbf{B}_{4} \mathbf{X}_{4}+e
$$

Keterangan:

$$
\begin{array}{llll}
\mathrm{Y} & =\text { Price Book Value } & \mathrm{X}_{2} & =\mathrm{ROE} \\
\mathrm{A} & =\text { Kontanta } & \mathrm{X}_{3} & =\mathrm{DER} \\
\mathrm{B}_{1}-\mathrm{b}_{4} & =\text { Koefisien regresi masing-masing } & \mathrm{X}_{4} & =\text { Ukuran Perusahaan } \\
\mathrm{X}_{1} & =\mathrm{CR} & \mathrm{e} & =\text { Kesalahan Pengganggu }
\end{array}
$$

\section{Pembahasan}

\subsection{Uji Asumsi Klasik}

4.1.1. Uji Normalitas

Dari gambar Grafik Normal P-Plot diperoleh hasil yang menunjukkan bahwa titik yang menyebar diantara garis diagonal dan mengikuti garis diagonalnya yang dapat diartikan bahwa nilai residual tersebut berdistribusi normal. Sehingga dapat disimpulkan persyaratan normalitas dapat terpenuhi dan layak digunakan dalam penelitian.

\subsubsection{Uji Multikolinieritas}

Dari Uji Multikolinieritas memperoleh hasil nilai Tolerance DER yaitu sebesar 0,999. Kemudian nilai Tolerance Ukuran Perusahaan 0,999. Dengan demikian dapat disebutkan bahwa Nilai Tolerance dari seluruh variabel bebas dalam penelitian ini < 10. Sedangkan Nilai VIF DER sebesar 1,001 kemudian nilai VIF Ukuran Perusahaan sebesar 1,001. Dengan demikian dapat disebutkan bahwa seluruh nilai VIF variabel bebas dalam penelitian ini >0,10, sehingga CR, ROE, DER dan Ukuran Perusahaan tidak terjadi masalah Multikolinieritas.

\subsubsection{Uji Heteroskedastisitas}

Hasil dari gambar Scatterplot yang didapat menunjukkan bahwa titik yang barada diatas angka 0 dan sumbu Y dan titik yang menyebar dengan acak dan tidak membentuk pola apapun. Hal tersebut dapat disimpukan bahwa data tersebut tidak terjadi masalah Heteroskedastisitas.

\subsubsection{Uji Autokoralasi}

Berdasarkan Uji Durbin Watson Test menunjukkan nilai Durbin Watson sebesar 2,138 yang posisinya berada diatara Nilai dU sebesar 1,7223 dan Nilai 4-dU sebesar 2,2777 yang artinya bahwa data tersebut tidak terjadi masalah Autokorelasi.

\subsection{Analisis Korelasi}

Dari hasil korelasi yang diperoleh, dapat diintepretasikan bahwa :

1. Nilai Signifikansi antara CR dengan PBV adalah 0,000 yang menunjukkan ada hubungan antara kedua variabel. Kemudian nilai koerfisien korelasi sebesar 0,516 yang artinya nilai korelasi tersebut bersifat positif dan sedang. Hubungan positif dapat diartikan bahwa jika CR naik maka PBV akan naik.

2. Nilai Signjfikansi antara ROE dengan PBV adalah 0,187 yang menunjukkan bahwa tidak adannya hubungan antar kedua variabel tersebut. 
3. Nilai signifikansi antara DER dengan PBV adalah 0,000 yang menujukkan adanya hubungan antara kedua variabel tersebut. Kemudian nilai koefisien korelasi sebesar -0,540 yang artinya nilai korelasi tersebut bersifat negative dan sedang. Hubungan negatif dapat diartikan bahwa jika Debt To Equity Ratio naik maka PBV akan turun.

4. Nilai Signifikansi antara Ukuran Perusahaan dengan PBV adalah sebsar 0,000 yang menunjukkan adanya hubungan antara kedua variabel tersebut. Kemudian nilai koefien korelasi sebesar 0,769 yang artinya nilai tersebut bersifat positif dan kuat. Hubungan positif dapat diartikan jika Ukuran Perusahaan naik maka PBV akan naik.

\subsection{Analisis Koefisien Determinasi}

Tabel 1. Analisis Koefisien Determinasi

\begin{tabular}{|c|c|c|c|}
\hline \multicolumn{4}{|c|}{ Model Summary } \\
\hline $\mathbf{R}$ & R Square & Adjusted R Square & $\begin{array}{l}\text { Std. Error of the } \\
\text { Estimate }\end{array}$ \\
\hline $.769^{a}$ & .591 & .580 & 1.655371 \\
\hline $.952^{b}$ & .906 & .900 & .806665 \\
\hline
\end{tabular}

Sumber : Output SPSS 20 dengan menggunakan metode Stepwise

Berdasarkan tabel 1 terdapat hasil Adjusted $R$ Square sebesar 0,900 atau 90\% yang artinya DER dan Ukuran Perusahaan mampu mempengaruhi PBV sebesar 90\%. Sisanya 10\% $(100 \%-90 \%=10 \%)$ dipengaruhi oleh variabel lain diluar penelitian ini seperti Pertumbuhan Perusahaan. Pertumbuhan Perusahaan dianggap mampu mempengaruhi PBV karena Pertumbuhan Perusahan digunakan untuk menghitung naik turunnya aktiva yang dimiliki oleh suatu perusahaan. Pertumbuhan Perusahan yang tinggi mencerminkan bahwa perusahaan tersebut sedang mengalami pertumbuhan atau perkembangan yang sangat baik sehingga dapat meningkatkan Nilai Perusahan. Hal Ini didukung oleh hasil penelitian Muhammad Ali (2016) dengan hasil yang diperoleh bahwa Pertumbuhan Perusahaan berpengaruh positif dan signifikan terhadap PBV.

\subsection{Analisis Regresi Linier Berganda}

Tabel 2. Coefficients ${ }^{\mathrm{a}}$

\begin{tabular}{|c|c|c|c|c|c|c|c|}
\hline \multirow[t]{2}{*}{ Model } & \multicolumn{2}{|c|}{$\begin{array}{l}\text { Unstandardized } \\
\text { Coefficients }\end{array}$} & $\begin{array}{c}\text { Standardized } \\
\text { Coefficients }\end{array}$ & \multirow[t]{2}{*}{$\mathrm{t}$} & \multirow[t]{2}{*}{ Sig. } & \multicolumn{2}{|c|}{$\begin{array}{l}\text { Collinearity } \\
\text { Statistics }\end{array}$} \\
\hline & B & Std. Error & Beta & & & Tolerance & VIF \\
\hline (Constant) & -98.583 & 14.354 & & -6.868 & .000 & & \\
\hline LN_UP_X4 & 31.627 & 4.381 & .769 & 7.219 & .000 & 1.000 & 1.000 \\
\hline (Constant) & -101.749 & 7.001 & & -14.534 & .000 & & \\
\hline 2 LN_UP_X4 & 32.234 & 2.136 & .784 & 15.092 & .000 & .999 & 1.001 \\
\hline LN_DER_X3 & -1.458 & .135 & -.561 & -10.798 & .000 & .999 & 1.001 \\
\hline
\end{tabular}

Sumber : Output SPSS 20 dengan menggunakan metode Stepwise

Berdasarkan tabel 2 dapat dilihat bahwa koefisien regresi antara PBV (Y) dipengaruhi oleh variabel DER dan Ukuran Perusahaan. Sehingga didapat persamaanya regresi linier berganda sebagai berikut:

$$
\text { LN_PBV_Y = -101,749 - 1,458 LN_DER_X3 + 32,234 LN_UP_X4 }
$$

Dari Persamaan koefisien regresi linier tersebut dapat diintepretasikan :

1. Konstanta : $-101,749$

Artinya : Jika DER dan Ukuran Perusahaan bernilai tetap atau (0) maka PBV -101,749.

2. Koefisien Regresi Variabel DER sebesar : $-1,458$ 
Artinya : Jika DER mengalami kenaikkan 1 kesatuan dan Ukuran Perusahaan bernilai tetap maka Price Book Value mengalami penurunan sebesar 1,458. Koefisien bernilai negatif yang artinya ada pengaruh negatif dan signifikan antara DER dengan PBV.

3. Koefiseien Regresi Variabel Ukuran Perusahaan sebesar : 32,234

Artinya : Jika Ukuran Perusahaan mengalami kenaikkan 1 kesatuan dan DER bernilai tetap maka Price Book Value akan mengalami kenaikkan pula sebesar 32,234. Koefisien bernilai positif yang artinya ada pengaruh positif dan signifikan antara Ukuran Perusahan dengan PBV.

\subsection{Uji $T$}

Tabel 3. Uji T

\begin{tabular}{|ll|r|r|r|r|r|}
\hline \multirow{2}{*}{ Model } & \multicolumn{2}{|c|}{$\begin{array}{c}\text { Unstandardized } \\
\text { Coefficients }\end{array}$} & $\begin{array}{c}\text { Standardized } \\
\text { Coefficients }\end{array}$ & \multicolumn{1}{c|}{$\mathrm{s}$} & \multirow{2}{*}{ Sig. } \\
\cline { 2 - 5 } & \multicolumn{1}{|c|}{$\mathrm{B}$} & Std. Error & \multicolumn{1}{c|}{ Beta } & & \\
\hline \multirow{2}{*}{1} & (Constant) & -98.583 & 14.354 & & -6.868 & .000 \\
& LN_UP_X4 & 31.627 & 4.381 & .769 & 7.219 & .000 \\
& (Constant) & -101.749 & 7.001 & & -14.534 & .000 \\
2 & LN_UP_X4 & 32.234 & 2.136 & .784 & 15.092 & .000 \\
& LN_DER_X3 & -1.458 & .135 & -.561 & -10.798 & .000 \\
\hline
\end{tabular}

Sumber : Output SPSS 20 dengan metode Stepwise

Berdasarkan tabel 3 dapat ditarik kesimpulkan sebagai berikut :

1. Uji Koefiseien Regresi Variabel DER

Hasil antara $t$ hitung dengan $t$ tabel adalah ( $\mathrm{t}$ hitung 10,798 $>\mathrm{t}$ tabel 2,0322) kemudian dapat dilihat dari hasil signifikansinya sebesar $0,000, \mathrm{H}_{0}$ ditolak dan $\mathrm{H}_{3}$ diterima sehingga ada pengaruh negatif dan signifikan antara DER dengan PBV,

2. Uji Koefiseien Regresi Variabel Ukuran Perusahaan

Hasil Antara t hitung dengan $t$ tabel adalah ( $t$ hitung 15,092 > t table 2,0322) kemudian dapat dilihat dari hasil signifikansinya sebesar $0,000, \mathrm{H}_{0}$ ditolak dan $\mathrm{H}_{4}$ diterima sehingga ada pengaruh positif dan signifikan antara Ukuran Perusahaan dengan PBV.

\subsection{Uji $F$}

Tabel 4. Uji F

\begin{tabular}{|ll|r|r|r|r|c|}
\hline Model & & Sum of Squares & \multicolumn{1}{|c|}{$\mathrm{df}$} & Mean Square & F & Sig. \\
\hline \multirow{3}{*}{1} & Regression & 142.789 & 1 & 142.789 & 52.108 & $.000^{\mathrm{b}}$ \\
& Residual & 98.649 & 36 & 2.740 & & \\
& Total & 241.438 & 37 & & & \\
& Regression & 218.664 & 2 & 109.332 & 168.019 & $.000^{\mathrm{c}}$ \\
& Residual & 22.775 & 35 & .651 & & \\
\hline & Total & 241.438 & 37 & & & \\
\hline
\end{tabular}

Sumber: Output SPSS 20 dengan metode Stepwise

Berdasarkan tabel 4 dapat diperoleh nilai signifikansi sebesar $0,000<0,05$, sehingga model regresi CR, ROE, DER dan Ukuran Perusahaan terhadap PBV dinyatakan layak dijadikan model dalam penelitian.

\subsection{Intepretasi Hasil Penelitian}

1. Pengaruh CR terhadap PBV

CR tidak memiliki pengaruh terhadap PBV. Hal ini tidak konsisten dengan Hipotesis yang menyebutkan bahwa CR berpengaruh signifikan terhadap PBV. Sebelumnya telah dijabarkan bahwa semakin tinggi CR menunjukkan bahwa perusahaan tersebut memiliki dana untuk membayar dividen dan sekaligus mempunyai dana internal yang besar. Namun CR di dalam 
perusahaan publik sub sektor kimia memiliki jumlah utang yang cenderung lebih meningkat dan kadang juga mengalami sedikit penurunan. CR yang terlalu besar menunjukkan perusahaan tersebut kurang mampu mengelola aktiva lancarnya sehingga mengakibatkan penjualan cenderung menurun. Hal ini sekaligus membuat para investor kurang tertarik sehingga dapat mengakibatkan harga saham menurun. Hasil penelitian ini sesuai dengan hasil penelitian yang dilakukan oleh Fitri Dwi Jayanti (2018) yang menunjukkan bahwa CR tidak berpengaruh signifikan terhadap PBV.

2. Pengaruh ROE terhadap $P B V$

ROE tidak memiliki pengaruh terhadap PBV. Hal ini tidak konsisten dengan Hipotesis yang menyebutkan bahwa ROE berpengaruh signifikan terhadap PBV. Sebelumnya telah dijabarkan bahwa semakin tinggi ROE maka semakin besar perusahaan tersebut dalam memperoleh suatu laba. Namun ROE di dalam perusahaan publilk sub sektor kimia memiliki pendapatan laba yang sedikit. ROE yang kecil potensi dividen yang dibagikan juga kecil atau bahkan tidak ada. Hal ini akan mengakibatkan para investor tidak tertarik untuk berinvestasi. Hasil penelitian ini sesuai dengan penelitian yang dilakukan oleh Heven Manopo Fitty dan Valdi Arie (2016) yang menunjukkan bahwa ROE tidak berpengaruh Signifikan terhadap PBV.

3. Pengaruh DER terhadap PBV

DER memiliki pengaruh negatif dan signifikan terhadap PBV. Hal ini kosisten dengan Hipotesis yang menyebutkan bahwa DER berpengaruh signifikan terhadap PBV. Sebelumnya telah dijabarkan bahwa rendahnya DER menunjukkan bahwa perusahaan memiliki kemampuan untuk membayar utang-utangnya dengan menggunakan modal (dana internal) yang dimiliki perusahaan. Sehingga perusahaan mampu membayar untuk membayar dividen pada para pemegang saham dengan tepat waktu dan hal ini dapat membuat para investor tertarik untuk melakukan investasi. Hasil penelitian ini sejalan dengan hasil penelitian yang dilakukan oleh Heven Manoppo Fitty dan Valdi Arie (2016) yang menunjukkan bahwa DER berpengaruh signifikan dengan PBV.

4. Pengaruh Ukuran Perusahaan terhadap PBV

Ukuran Perusahaan berpengaruh positif dan signifikan terhadap PBV. Hal ini konsisten dengan Hipotesis yang menyebutkan bahwa Ukuran Perusahaan berpengaruh signifikan terhadap PBV. Sebelumnya telah dijabarkan bahwa Ukuran Perusahaan yang tinggi atau perusahaan yang berskala tinggi akan dengan mudah memperoleh dana internal maupun dan eksternal. Ukuran Perusahaan yang besar bias menjamin nilai perusahaannya tinggi karena perusahaan yang besar akan berani melakukan investasi baruterkait dengan ekspansi, sebelum kewajiban-kewajiban (utang) sudah terlunasi. Hasil ini sejalan penelitian Gusti Ngurah Ruganda dan Gede Merta Sudiarta (2016) yang menunjukkan bahwa Ukuran Perusahaan berpengaruh signifikan terhadap PBV.

\section{Kesimpulan}

Berdasarkan hasil penetian yang telah dilakukan maka diperoleh kesimpulan bahwa DER dan Ukuran Perusahaan memiliki pengaruh signifikan terhadap PBV. Sedangkan CR dan ROE tidak memiliki pengaruh terhadap PBV pada perusahaan publik sub sektor kimia yang terdaftar di Bursa Efek Indonesia Periode 2013-2017.

Dari hasil penelitian ini dapat disampaikan kepada pihak perusahan, diharapkan hasil penelitian ini dapat dijadaikan bahan atau gambaran untuk mempertimbangkan kondisi bagi perusahaan sub sektor kimia agar dapat berkembang dan hendaknya dapat memperhatikan faktor-faktor yang dapat mempengaruhi PBV seperti DER dan Ukuran parusahaan. Kemudian bagi investor, diharapkan hasil penelitian ini dijadikan gambaran untuk melakukan investasi pada perusahaan publik sub sektor kimia dalam kurun waktu jangka pendek atau jangka panjang dengan melihat kondisi perusahaan tersebut dan dapat dilihat pula dari faktor-faktor yang mempengaruh PBV seperti DER dan Ukuran Perusahaan.

\section{Referensi}

Fahmi, Irham. (2017). Analisis Laporan Keuangan. Bandung: Alfabeta.

Harahap, Sofyan Safri. (2015). Analisis Kritis atas Laporan Keuangan. Edisi 10. Jakarta: PT Raja Grafindo Persada.

Harjadi, S. (2015). Pasar Uang Pasar Modal. Cetakan Pertama. Bogor: In Media.

Harmono. (2017). Manajemen Keuangan. Edisi 1. Cetakan Keenam, Jakarta: Numi Aksara. 
Hermanto, Bambang dan Mulyo Agung. (2015). Analisis Laporan Keuangan Lanjutan. Cetakan Keempat. Jakarta; Lentera Ilmu.

Hery. (2018). Analis Laporan Keuangan. Edisi 1. Jakarta: PT Raja Grafindo Persada.

Heven Manoppo dan Fitty Valdy Arie. (2016). Pengaruh Struktur Modal, Ukuran Perusahaan dan Profitabilitas Terhadap Nilai Perusahaan Otomotif Yang Terdaftar Di Bursa Efek Indonesia Periode 2011-2014. E-Jurnal EMBA. 4(2): 2303-1174.

I Gusti Ngurah Gede Ruganda dan Gede Merta Sudirta. (2016). Analisis Pengaruh Ukuran Perusahaan, Laverage, dan Profitabilitas Terhadap Nilai Perusahaan. E-Jurnal Manajemen UNUD. 5(7): 4394-4422.

Jayanti, Fitri Dwi. Analisis Pengaruh Profitabilitas, Struktur Modal, Likuiditas dan Ukuran Perusahaan Terhadap NIlai Perusahaan. E-Jurnal Bingkai Ekonomi UNISS. 3(2): 2510-1818.

Muhammad Ali. (2016). Pengaruh Return On Equity (ROE), Debt To Equity Ratio (DER) dan Growth Terhadap Price Book Value (Studi Kasus Pada Perusahaan Manufaktur Sub Sektor Food and Bevarage Yang Terdaftar Di Bursa Efek Indonesia Periode 2010-2014). E- Jurnal Conference On Management and Behavioral Studies. 2541-3400. 